\title{
Lymphocyte subpopulations during cytomegalovirus disease in renal transplant recipients
}

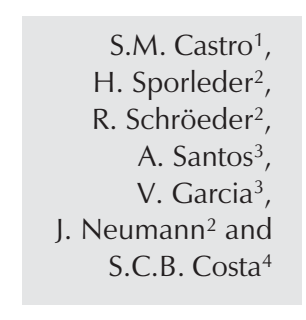

\author{
${ }^{1}$ Departamento de Farmacologia, Faculdade de Ciências Médicas, \\ Universidade Estadual de Campinas, Campinas, SP, and Faculdade de Farmácia, \\ Universidade Federal do Rio Grande do Sul, Porto Alegre, RS, Brasil \\ ${ }^{2}$ Laboratório de Immunologia de Transplante, and \\ ${ }^{3}$ Departamento de Nefrologia, Hospital da Santa Casa, Porto Alegre, RS, Brasil \\ ${ }^{4}$ Departamento de Clínica Médica, Faculdade de Ciências Médicas, \\ Universidade Estadual de Campinas, Campinas, SP, Brasil
}

\section{Correspondence \\ S.C.B. Costa \\ Disciplina de Medicina Interna \\ Departamento de Clínica Médica \\ FCM, UNICAMP \\ 13081-970 Campinas, SP \\ Brasil \\ Fax: +55-19-3289-4107 \\ E-mail: costa@fcm.unicamp.br}

Publication supported by FAPESP.

Received September 4, 2001

Accepted January 6, 2003

\begin{abstract}
We have determined the number of circulating $\mathrm{T}, \mathrm{B}$ and natural killer cells in renal transplant recipients in order to detect changes during cytomegalovirus (CMV) infections. Serial blood samples were taken from 61 patients on standard triple immunosuppression therapy (cyclosporin A, azathioprine and prednisone). Using two-color flow cytometry analysis, the absolute number of CD3+, CD4+, CD8+, CD19+, CD3+HLA-DR+ and CD16+56+ cells was determined. Fortyeight patients $(78.7 \%$ ) developed active CMV infection, and all of them subsequently recovered. Twenty of the infected patients (32.8\%) presented symptoms compatible with CMV disease during the infectious process. The number of lymphocytes and their main subpopulations were normal before the onset of CMV disease. During the disease there was a decrease followed by a significant increase $(\mathrm{P}<0.005)$ in the number of $\mathrm{CD} 3+, \mathrm{CD} 4+, \mathrm{CD} 8+$ and $\mathrm{CD} 3+\mathrm{HLA}-$ $\mathrm{DR}+$ cells. No significant changes were observed in natural killer cells or B lymphocytes during the disease. We conclude, as observed in all viremic patients recovering from infection, that recovery is associated with an increase in the number of $\mathrm{T}$ cell subsets. The monitoring of different lymphocyte subsets along with antigenemia can be extremely useful in the detection of patients at high risk of developing CMV symptoms, allowing the early introduction of antiviral therapy or the reduction of immunosuppression therapy.
\end{abstract}

\section{Introduction}

Cytomegalovirus (CMV) is one of the most important causes of infectious complications in organ transplant recipients $(1,2)$. It occurs in $43-92 \%$ of kidney transplant recipients during the first months after trans-
Key words

- Transplantation

- Cytomegalovirus

- Antigenemia

- T lymphocytes plantation and is associated with a greater net state of immunosuppression (3). In immunocompromised individuals it may be reactivated from its latency and cause asymptomatic or symptomatic infection, with severe illness that may result in high mortality $(4,5)$. CMV infection can occur in both sero- 
positive and seronegative patients (6). The incidence and intensity of the infection are largely determined by the recipient's pretransplant CMV serostatus, with seronegative recipients of seropositive donors having the highest risk for a serious primary infection. Reinfections may also be symptomatic and severe, probably because of the fact that a reinfection by a different strain of CMV transmitted via the seropositive allograft is also possible (7). In addition, antilymphocyte immunoglobulin (antithymocyte globulin, antilymphocyte globulin, OKT3 monoclonal antibodies), used either as induction therapy or for allograft rejection treatment, and the total dose of corticosteroids enhance the rate of symptomatic CMV infection, especially in CMV-seropositive individuals (8).

The immune response against $\mathrm{CMV}$ is complex and not fully understood. It is unable to eliminate the virus completely, allowing it to persist in a latent state. The CMV infection is known to cause changes in peripheral blood lymphocyte subpopulations. A fast detection of CMV in peripheral blood has been the goal of several studies in order to correlate viremia and a clinical response. However, while monitoring CMV disease, we should also consider how much the immune cell response is compromised.

Immunophenotyping has not been indicated as relevant for the diagnosis of CMV disease (9), but is considered important in the elucidation of immune processes that involve pre- and post-infection stages (9). For this reason, immunological assays using peripheral blood lymphocytes should be considered. Results obtained with murine models and observations on human material have demonstrated the importance of $\mathrm{T}$ lymphocytes and natural killer (NK) cells in the recovery from CMV infections $(5,10)$.

In the present study we monitored lymphocyte subpopulations weekly, from pretransplantation to the 12th week post-transplant, and correlated these results with $\mathrm{CMV}$ disease events. We measured the subsets of different lymphocyte populations, including NK cells, in peripheral blood at weekly intervals for 12 weeks post-renal transplantation, regardless of the presence or absence of CMV disease. We examined only phenotypic changes in different cell populations, without measuring their specificity or function.

\section{Material and Methods}

\section{Patients and management}

Sixty-one consecutive adult renal transplant recipients, with or without CMV infection, were studied prospectively. Baseline immunosuppression consisted of a standard triple drug regimen consisting of cyclosporin A in combination with prednisone and azathioprine. None of the patients had received hyperimmune globulin or high-dose oral acyclovir as prophylaxis against CMV. Transplant rejections were documented by biopsy and treated with methylprednisolone pulses; steroid-resistant rejection was treated with OKT3. In cases of symptomatic CMV infection, immunosuppression was reduced as a first-line measure. Ganciclovir was given when organs were involved or when CMV disease was clinically judged to be severe. The decision to initiate antiviral therapy was made on a clinical basis, and on the basis of the number of antigen-positive cells and without prior knowledge of the lymphocyte activation status. The data of the patients studied are summarized in Table 1.

\section{Blood samples}

The presence of CMV antigenemia in peripheral blood and lymphocyte phenotyping were assessed in pre-transplant blood samples from the recipients before the administration of immunosuppressive drugs and in post-transplant samples once a week until the 12th week after transplantation. 
Table 1. Characteristics of renal transplant donors and recipients.

\begin{tabular}{|c|c|c|c|c|c|c|}
\hline \multirow[t]{2}{*}{ Recipient } & \multirow[t]{2}{*}{ Sex } & \multirow{2}{*}{$\begin{array}{l}\text { Age } \\
\text { (years) }\end{array}$} & \multicolumn{2}{|c|}{ Type of donor } & \multirow{2}{*}{$\begin{array}{l}\text { Immunosuppression } \\
\text { (Solumedrol, g) }\end{array}$} & \multirow{2}{*}{$\begin{array}{c}\text { Donor/recipient } \\
\text { pre-transplantation serology } \\
\text { (ELISA) }\end{array}$} \\
\hline & & & Date & Type & & \\
\hline 1 & $M$ & 39 & $01 / 11 / 96$ & $\mathrm{C}$ & 3.0 & $+/+$ \\
\hline 2 & $\mathrm{M}$ & 37 & $01 / 11 / 96$ & $\mathrm{C}$ & 3.0 & $+/+$ \\
\hline 3 & $\mathrm{M}$ & 68 & $01 / 21 / 96$ & $\mathrm{C}$ & 0 & $\mathrm{ND} /+$ \\
\hline 4 & $\mathrm{~F}$ & 55 & $01 / 21 / 96$ & C & 1.5 & $\mathrm{ND} /+$ \\
\hline 5 & $\mathrm{M}$ & 43 & $01 / 30 / 96$ & C & 2.5 & ND/- \\
\hline 6 & $\mathrm{M}$ & 48 & $01 / 30 / 96$ & C & 0 & $\mathrm{ND} /+$ \\
\hline 7 & $\mathrm{~F}$ & 65 & $02 / 06 / 96$ & $\mathrm{R}$ & 0 & $+/+$ \\
\hline 8 & $\mathrm{M}$ & 39 & $02 / 13 / 96$ & $\mathrm{R}$ & 3.5 & $+/+$ \\
\hline 9 & $\mathrm{~F}$ & 23 & $02 / 22 / 96$ & C & 3.0 & $\mathrm{ND} /+$ \\
\hline 10 & $\mathrm{M}$ & 34 & $02 / 29 / 96$ & $\mathrm{C}$ & 2.75 & $+/+$ \\
\hline 11 & $\mathrm{~F}$ & 26 & $02 / 29 / 96$ & C & $2.0+$ OKT3 & $+/+$ \\
\hline 12 & $\mathrm{~F}$ & 25 & $03 / 05 / 96$ & $\mathrm{R}$ & 0 & $\mathrm{ND} /+$ \\
\hline 13 & $\mathrm{~F}$ & 26 & $03 / 13 / 96$ & C & 0 & $\mathrm{ND} /+$ \\
\hline 14 & $\mathrm{M}$ & 60 & $03 / 14 / 96$ & $\mathrm{C}$ & 1.75 & $\mathrm{ND} /+$ \\
\hline 15 & $\mathrm{~F}$ & 28 & $04 / 02 / 96$ & $\mathrm{R}$ & 3.0 & $+/+$ \\
\hline 16 & $\mathrm{~F}$ & 67 & $04 / 13 / 96$ & C & 2.25 & $+/+$ \\
\hline 17 & $\mathrm{~F}$ & 33 & $04 / 14 / 96$ & C & 1.875 & $+/+$ \\
\hline 18 & $\mathrm{M}$ & 46 & $04 / 17 / 96$ & C & 3.75 & $\mathrm{ND} /+$ \\
\hline 19 & $\mathrm{M}$ & 38 & $04 / 17 / 96$ & C & 3.0 & $\mathrm{ND} /+$ \\
\hline 20 & $\mathrm{M}$ & 53 & $04 / 22 / 96$ & C & 2.25 & $+/+$ \\
\hline 21 & $\mathrm{~F}$ & 25 & $04 / 22 / 96$ & C & 3.75 & $+/+$ \\
\hline 22 & $\mathrm{M}$ & 28 & $05 / 07 / 96$ & $\mathrm{R}$ & 1.75 & $-1+$ \\
\hline 23 & $\mathrm{M}$ & 37 & 05/09/96 & $\mathrm{R}$ & 4.75 & $+/+$ \\
\hline 24 & $\mathrm{~F}$ & 34 & $05 / 21 / 96$ & $\mathrm{R}$ & $3.5+$ OKT3 & $+/+$ \\
\hline 25 & $\mathrm{M}$ & 64 & $05 / 28 / 96$ & $\mathrm{R}$ & 3.75 & $+/+$ \\
\hline 26 & $\mathrm{M}$ & 41 & $06 / 10 / 96$ & C & 6.0 & $\mathrm{ND} /+$ \\
\hline 27 & $\mathrm{~F}$ & 22 & $06 / 18 / 96$ & $\mathrm{R}$ & 0 & $+/+$ \\
\hline 28 & $\mathrm{M}$ & 20 & $06 / 26 / 96$ & C & 4.5 & ND/- \\
\hline 29 & $\mathrm{M}$ & 21 & $07 / 12 / 96$ & C & 4.0 & $+/-$ \\
\hline 30 & $\mathrm{~F}$ & 57 & $07 / 12 / 96$ & C & 2.25 & $+/+$ \\
\hline 31 & $\mathrm{~F}$ & 28 & $07 / 18 / 96$ & $\mathrm{R}$ & 0 & $+/+$ \\
\hline 32 & $\mathrm{~F}$ & 19 & $07 / 23 / 96$ & $\mathrm{R}$ & 0 & $+/+$ \\
\hline 33 & $\mathrm{M}$ & 46 & $07 / 29 / 96$ & C & 2.25 & $+/+$ \\
\hline 34 & $\mathrm{M}$ & 45 & $07 / 30 / 96$ & $\mathrm{R}$ & 3.75 & $+/+$ \\
\hline 35 & $\mathrm{~F}$ & 24 & $08 / 13 / 96$ & $\mathrm{R}$ & 0 & $+/+$ \\
\hline 36 & $\mathrm{M}$ & 23 & $08 / 28 / 96$ & C & 1.5 & $+/+$ \\
\hline 37 & $\mathrm{~F}$ & 40 & $08 / 28 / 96$ & C & 1.5 & $+/+$ \\
\hline 38 & $M$ & 55 & $09 / 10 / 96$ & $\mathrm{R}$ & 0 & $+/+$ \\
\hline 39 & $\mathrm{~F}$ & 15 & $09 / 17 / 96$ & $\mathrm{R}$ & 1.5 & $+/+$ \\
\hline 40 & $\mathrm{~F}$ & 36 & $09 / 23 / 96$ & C & 3.0 & $+/+$ \\
\hline 41 & $\mathrm{M}$ & 60 & $09 / 26 / 96$ & C & 3.75 & $-1+$ \\
\hline 42 & $\mathrm{M}$ & 42 & $10 / 01 / 96$ & $\mathrm{R}$ & 0 & $+/+$ \\
\hline 43 & $\mathrm{M}$ & 54 & $10 / 12 / 96$ & C & 1.5 & $+/-$ \\
\hline 44 & $\mathrm{~F}$ & 18 & $10 / 13 / 96$ & C & 0.75 & $+/-$ \\
\hline 45 & $\mathrm{M}$ & 48 & $10 / 15 / 96$ & $\mathrm{R}$ & 0.75 & $+/+$ \\
\hline 46 & $\mathrm{~F}$ & 27 & $10 / 18 / 96$ & $\mathrm{C}$ & 4.75 & $+/+$ \\
\hline 47 & $\mathrm{~F}$ & 56 & $10 / 18 / 96$ & C & 0 & $+/+$ \\
\hline 48 & $\mathrm{~F}$ & 43 & $10 / 29 / 96$ & $\mathrm{R}$ & 0.75 & $+/+$ \\
\hline 49 & $\mathrm{~F}$ & 19 & $11 / 11 / 96$ & $\mathrm{C}$ & 0.75 & $\mathrm{ND} /+$ \\
\hline 50 & $\mathrm{~F}$ & 52 & $11 / 20 / 96$ & C & 0 & $\mathrm{ND} /+$ \\
\hline 51 & $\mathrm{M}$ & 55 & $11 / 20 / 96$ & $\mathrm{C}$ & 2.0 & $\mathrm{ND} /+$ \\
\hline
\end{tabular}




\begin{tabular}{|c|c|c|c|c|c|c|}
\hline \multirow[t]{2}{*}{ Recipient } & \multirow[t]{2}{*}{ Sex } & \multirow{2}{*}{$\begin{array}{l}\text { Age } \\
\text { (years) }\end{array}$} & \multicolumn{2}{|c|}{ Type of donor } & \multirow{2}{*}{$\begin{array}{l}\text { Immunosuppression } \\
\text { (Solumedrol, g) }\end{array}$} & \multirow{2}{*}{$\begin{array}{c}\text { Donor/recipient } \\
\text { pre-transplantation serology } \\
\text { (ELISA) }\end{array}$} \\
\hline & & & Date & Type & & \\
\hline 52 & $\mathrm{M}$ & 37 & $11 / 26 / 96$ & $\mathrm{R}$ & 0 & $+/+$ \\
\hline 53 & $\mathrm{M}$ & 49 & $12 / 04 / 96$ & C & 2.25 & $+/+$ \\
\hline 54 & $F$ & 31 & $12 / 05 / 96$ & C & 0 & $+/+$ \\
\hline 55 & $\mathrm{M}$ & 29 & $12 / 08 / 96$ & C & 3.25 & $\mathrm{ND} /+$ \\
\hline 56 & $M$ & 61 & $12 / 08 / 96$ & C & $0.375+$ OKT3 & $\mathrm{ND} /+$ \\
\hline 57 & $\mathrm{M}$ & 16 & $12 / 10 / 96$ & $\mathrm{R}$ & $2.875+$ OKT3 & $+/+$ \\
\hline 58 & $M$ & 44 & $12 / 14 / 96$ & C & 0 & $\mathrm{ND} /+$ \\
\hline 59 & $\mathrm{M}$ & 29 & $12 / 17 / 96$ & $\mathrm{R}$ & 0 & $+/+$ \\
\hline 60 & $\mathrm{M}$ & 31 & $12 / 31 / 96$ & $\mathrm{C}$ & 2.5 & $+/+$ \\
\hline 61 & $M$ & 24 & $12 / 31 / 96$ & C & 1.875 & $+/+$ \\
\hline
\end{tabular}

R: related donor, C: cadaver donor, OKT3: antilymphocyte $\mathrm{T},(+)$ : positive serology for CMV, (-): negative serology for CMV, ND: not determined.

\section{Virological methods}

CMV antigenemia was determined as described previously (11), using the Clonab CMV - APAAP kit(Art. No. 812680, Biotest, Dreilich, Germany). Briefly, peripheral blood leukocytes were stained with immunoperoxidase using a mixture of monoclonal antibodies $\mathrm{C} 10$ and $\mathrm{C} 11$, directed against the $65-$ $\mathrm{kDa}$ CMV lower matrix phosphoprotein (12). The number of antigen-positive cells per $10^{5}$ polymorphonuclear leukocytes was counted and designated as the viral load. IgG and IgM antibodies against CMV were determined by ELISA.

\section{Lymphocyte immunophenotyping}

A whole-blood staining method was used with the following monoclonal antibodies (Becton Dickinson, San Jose, CA, USA): anti-CD3-fluorescent isothiocyanate (T lymphocytes), anti-CD4-phycoerythrin (PE) (TCD4 cells), anti-CD8-PE (TCD8 cells or NK cells), anti-CD19-PE (B cells), antiCD16+56-PE (NK cells), and anti-HLA-DRPE (activated T, B or NK cells). A total of 2,500 cells in a lymphocyte gate were analyzed with an Ortho Cytoron Absolute Flow
Cytometer (Ortho Diagnostic Systems Inc., Raritan, NJ, USA). Absolute numbers of cells were obtained using the same equipment.

Forty-one patients without clinical evidence of CMV disease 3 months after transplantation (at a time when all patients with CMV infection had manifested subset changes) served as controls.

\section{Occurrence of CMV infection}

Active CMV infection was defined by the presence of antigenemia in peripheral blood. Infection was considered to be primary when the patient was CMV seronegative before transplantation and secondary in the presence of pre-transplant IgG antibodies against CMV (13).

Symptoms consistent with CMV disease include fever, leukopenia, thrombocytopenia and/or elevation in serum transaminase levels (14). The diagnostic criteria for symptomatic CMV disease used in our study followed the recommendations made by the Workshop on Human CMV Disease (15). Work-up for microorganisms other than CMV included multiple bacteriological and fungal cultures of blood, urine and sputum, as well as serological tests and multiple chest 
$\mathrm{X}$-rays. CMV isolation was not attempted. Informed consent was obtained from all patients and the protocol was approved by the Hospital's Ethics Committee.

\section{Statistical analysis}

Since the data were not distributed normally, the results are reported as medians. Differences between two groups were compared by the Mann-Whitney U-test. Differences at this level were then determined by the minimum significant difference test after K-W ANOVA (ZAR or Altam). The significance level adopted was $\alpha=0.05$. All data were processed and analyzed with the programs Epi-Info V4 and Statistical Package for Social Sciences - SPSS V6.

\section{Results}

Sixty-one adult kidney graft recipients transplanted at Santa Casa Hospital, Porto Alegre, Brazil, were studied before transplantation and for 12 weeks after transplantation, from January to December 1996. Of the 61 patients studied, $41(67.2 \%)$ did not show evidence of CMV disease in the first 3 months post-transplantation. Of these 41 patients, 28 (68.3\%) presented active CMV infection at some time during the study, while the remaining $13(31.7 \%)$ did not. Twenty (32.8\%) patients showed symptoms compatible with mild or severe CMV disease at some point during the 3-month study period. The average time for the occurrence of CMV infection was 6 weeks post-transplantation, ranging from 4 to 11 weeks. Of the 20 patients with CMV disease, $8(40.0 \%)$ had a mild disease with leukopenia, fever and thrombocytopenia, and $12(60.0 \%)$ presented severe CMV disease with fever and/or leukopenia and/or pericarditis and/or thrombocytopenia and/or hepatitis and/or gastroenteritis and/or rejection, requiring treatment with ganciclovir. Of the 20 patients likely to have CMV disease, 17 (85.0\%) were posi- tive for antigenemia before or during the appearance of any clinical manifestation attributable to CMV disease, and the other 3 were positive for antigenemia after the appearance of the clinical symptoms. All patients with symptomatic infection healed spontaneously or after treatment with an antiviral drug (Tables 2 and 3).

\section{Immunophenotyping of lymphocyte subpopulations}

No cell population studied showed a statistically significant difference in its absolute values before transplantation.

\section{T lymphocytes (CD3+)}

During the first week post-transplantation, no alteration occurred in the absolute values of the total $\mathrm{T}$ lymphocyte population compared to the pre-transplantation period in either group $(\mathrm{P}=0.3035)$. From week 2 to week 12 post-transplantation, the group with CMV disease showed lower T lymphocyte levels than the group without CMV disease. This difference between the two groups was statistically significant from week $2(\mathrm{P}=$ $0.0121)$ through week $8(\mathrm{P}=0.0204)$. In the second month posttransplantation, the group with disease showed the lowest $\mathrm{T}$ lympho-

\begin{tabular}{|c|c|c|c|c|}
\hline \multirow{2}{*}{$\begin{array}{l}\text { Pre-transplantation } \\
\text { (lgG) }\end{array}$} & \multicolumn{2}{|c|}{ Without CMV disease } & \multicolumn{2}{|c|}{ With probable CMV disease } \\
\hline & $\begin{array}{l}\text { without active } \\
\text { infection }\end{array}$ & $\begin{array}{l}\text { with active } \\
\text { infection }\end{array}$ & mild disease & severe disease \\
\hline D-/R- & 0 & 0 & 0 & 0 \\
\hline $\mathrm{D}-/ \mathrm{R}+$ & 1 & 0 & 0 & 1 \\
\hline$D+/ R-$ & 0 & 0 & 0 & 3 \\
\hline $\mathrm{D}+/ \mathrm{R}+$ & 10 & 15 & 6 & 7 \\
\hline Donor ND/R+ & 2 & 12 & 2 & 0 \\
\hline Donor ND/R- & 0 & 1 & 0 & 1 \\
\hline Total & 13 & 28 & 8 & 12 \\
\hline
\end{tabular}


cyte levels, coinciding with the period of greater incidence of the disease in our study. From week 8 on, T lymphocyte values started to increase in the group with disease, reaching a peak at week $10(\mathrm{P}=0.0302)$ and returning to baseline at week $12(\mathrm{P}=0.1150)$. Starting at week 2 post-transplantation, the group without CMV disease always presented $50 \%$ higher T lymphocytes values $(\mathrm{P}=0.000)$ compared to the pre-transplantation period (Figure 1).

\section{TCD4 cells $(\mathrm{CD} 3+\mathrm{CD} 4+)$}

Prior to week 2 post-transplantation there were no significant alterations in TCD4 cell values in either group. From week 2 to week 12 post-transplantation, the group with $\mathrm{CMV}$ disease showed significantly lower absolute TCD4 cell values $(\mathrm{P}=0.0003)$ than the group without disease. Between week 5 and 7 the group with disease reached its minimum TCD4 cell values, coinciding with the period of greater disease incidence in our study. From week 8 on, TCD4 cell number started to increase in the group with CMV disease, remaining significantly lower than in the group without CMV disease until week 12 (Figure 2).

\section{TCD8 cells $(\mathrm{CD} 3+\mathrm{CD8}+)$}

During week 1 post-transplantation there was a decrease in the total count of TCD8 cells in both groups. From week 2 posttransplantation on, the group with disease showed still decreasing TCD8 cell values, reaching minimum values at week 7 . The differences between the two groups were statistically significant from week 2 to week $7(\mathrm{P}=0.003)$. From week 8 on, TCD8 cell values in the group with $\mathrm{CMV}$ disease started to increase, reaching values close to baseline at week 12. The group without CMV disease had higher values than baseline from week 2 to the end of the 3-month post-transplantation period (Figure 3).

Table 3. Clinical manifestations, treatment and outcome of the graft of the 20 patients with probable cytomegalovirus (CMV) disease.

\begin{tabular}{|c|c|c|c|c|c|}
\hline Patient & $\begin{array}{l}\text { Signs, symptoms and laboratory } \\
\text { alterations }\end{array}$ & $\begin{array}{l}\text { Post-transplantation time } \\
\text { at the beginning of clinical } \\
\text { manifestations (weeks) }\end{array}$ & $\begin{array}{l}\text { Classification } \\
\text { of CMV disease }\end{array}$ & $\begin{array}{c}\text { Treatment } \\
\text { (ganciclovir) } \\
10 \mathrm{mg} \mathrm{kg}^{-1} \text { day }^{-1} \text { (days) }\end{array}$ & Outcome \\
\hline 2 & Fever, leukopenia, gastroenteritis & 8 & SD & 24 & Functionir \\
\hline 10 & Fever, leukopenia & 7 & SD & 21 & Functioning \\
\hline 11 & Fever, leukopenia, pericarditis & 4 & SD & 21 & Functioning \\
\hline 16 & Leukopenia, thrombocytopenia & 2 & $\mathrm{MD}$ & Not treated & Functioning \\
\hline 17 & Leukopenia, colitis & 9 & MD & Not treated & Functioning \\
\hline 20 & Fever, leukopenia, thrombocytopenia & 4 & SD & 14 & Functioning \\
\hline 22 & Fever, blister injuries on skin & 7 & SD & 14 & Functioning \\
\hline 24 & Fever, leukopenia & 4 & SD & 14 & Functioning \\
\hline 25 & Leukopenia & 6 & MD & Not treated & Functioning \\
\hline 28 & Fever, leukopenia, epigastric pain & 4 & SD & 14 & Functioning \\
\hline 29 & Fever, leukopenia, gastritis & 7 & SD & 14 & Functioning \\
\hline 30 & Leukopenia & 8 & $\mathrm{MD}$ & Not treated & Functioning \\
\hline 40 & Leukopenia & 11 & SD & Not treated & Functioning \\
\hline 43 & Leukopenia, hepatitis & 7 & SD & 14 & Functioning \\
\hline 44 & Fever, leukopenia, myalgia & 4 & SD & 14 & Functioning \\
\hline 46 & Fever, leukopenia & 5 & SD & 21 & Functioning \\
\hline 47 & Leukopenia & 6 & SD & Not treated & Functioning \\
\hline 53 & Leukopenia & 4 & $M D$ & Not treated & Functioning \\
\hline 56 & Leukopenia & 5 & MD & Not treated & Functioning \\
\hline 58 & Fever, leukopenia & 5 & MD & Not treated & Functioning \\
\hline
\end{tabular}

SD: severe disease, MD: mild disease. 


\section{B lymphocytes (CD19+)}

During the first and second week posttransplantation an increase in the total number of B lymphocytes was observed both in the group without CMV and in the group with CMV disease. From the third week there was a decrease in B lymphocyte values in both groups. In the group without the disease, values remained higher than baseline during the 3-month study period, and in the group with disease, values remained lower than baseline from week 3 to week 12 posttransplantation. There were significant differences in B lymphocyte number between groups at week 4 and $7(P=0.0076)$ (data not shown).

\section{Activated T lymphocytes (CD3+HLA-DR+)}

In the group with CMV disease the numbers of activated $\mathrm{T}$ lymphocytes tended to decrease from week 1 to week 7 post-transplantation. From week 8, values increased, reaching the levels of the pre-transplantation period at week 12. The group without the disease continued to show values close to baseline throughout the 3 months of the study. At week 6 post-transplantation, both groups showed statistically significant differences in total activated $\mathrm{T}$ lymphocyte values $(\mathrm{P}=0.0422)$ (Figure 4$)$.

\section{NK cells $(C D 3-C D(16+56)+)$}

NK cell numbers were reduced by about $50 \%$ of their baseline values at week 1 posttransplantation, remaining low until week 12 in both groups. At week 7 the levels of NK cells decreased significantly in the group with CMV disease $(\mathrm{P}=0.0155)$ (data not shown).

\section{Discussion}

Cytomegalovirus is one of the most im-

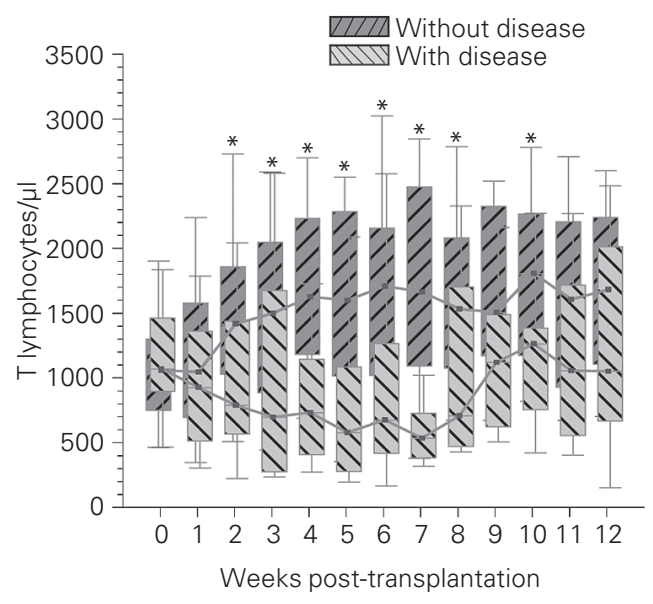

Figure 1. $\mathrm{T}(\mathrm{CD} 3+)$ lymphocyte concentration in blood among renal transplant patients with and without probable CMV disease. Data are reported as medians \pm interquartile range for 61 patients. ${ }^{*} \mathrm{P}<0.05$ compared to CMV-positive patients (MannWhitney U-test).
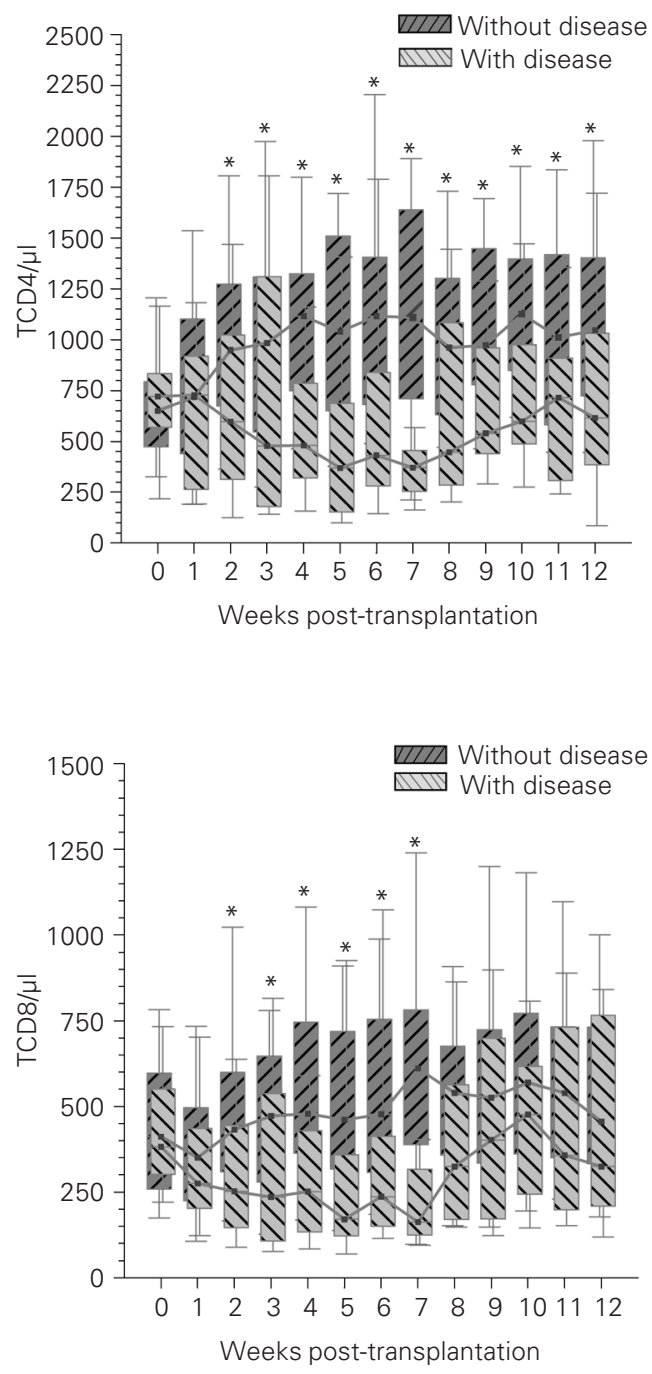

Figure 2. TCD4 cell concentration in blood among renal transplant patients with and without probable CMV disease. Data are reported as medians \pm interquartile range for 61 patients. ${ }^{*} \mathrm{P}<0.05$ compared to CMV-positive patients (Mann-Whitney Utest).
Figure 3. TCD8 cell concentration in blood among renal transplant patients with and without probable CMV disease. Data are reported as medians \pm interquartile range for 61 patients. ${ }^{*} \mathrm{P}<0.05$ compared to CMV-positive patients (Mann-Whitney Utest). 
Figure 4. Activated T lymphocyte concentration in blood among renal transplant patients with and without probable CMV disease. Data are reported as medians \pm interquartile range for 61 patients. ${ }^{*} P<0.05$ compared to CMV-positive patients (MannWhitney U-test). portant infectious agents that attack transplant patients and is responsible for the significant morbidity and mortality presented by organ recipients $(2,16)$.

Since antigenemia started to be used as a quantitative marker of viral load, more extensive studies on the interaction between CMV and host immune response have become possible. This is a rapid, sensitive and specific technique (17-19). The early detection of viral antigens in peripheral blood
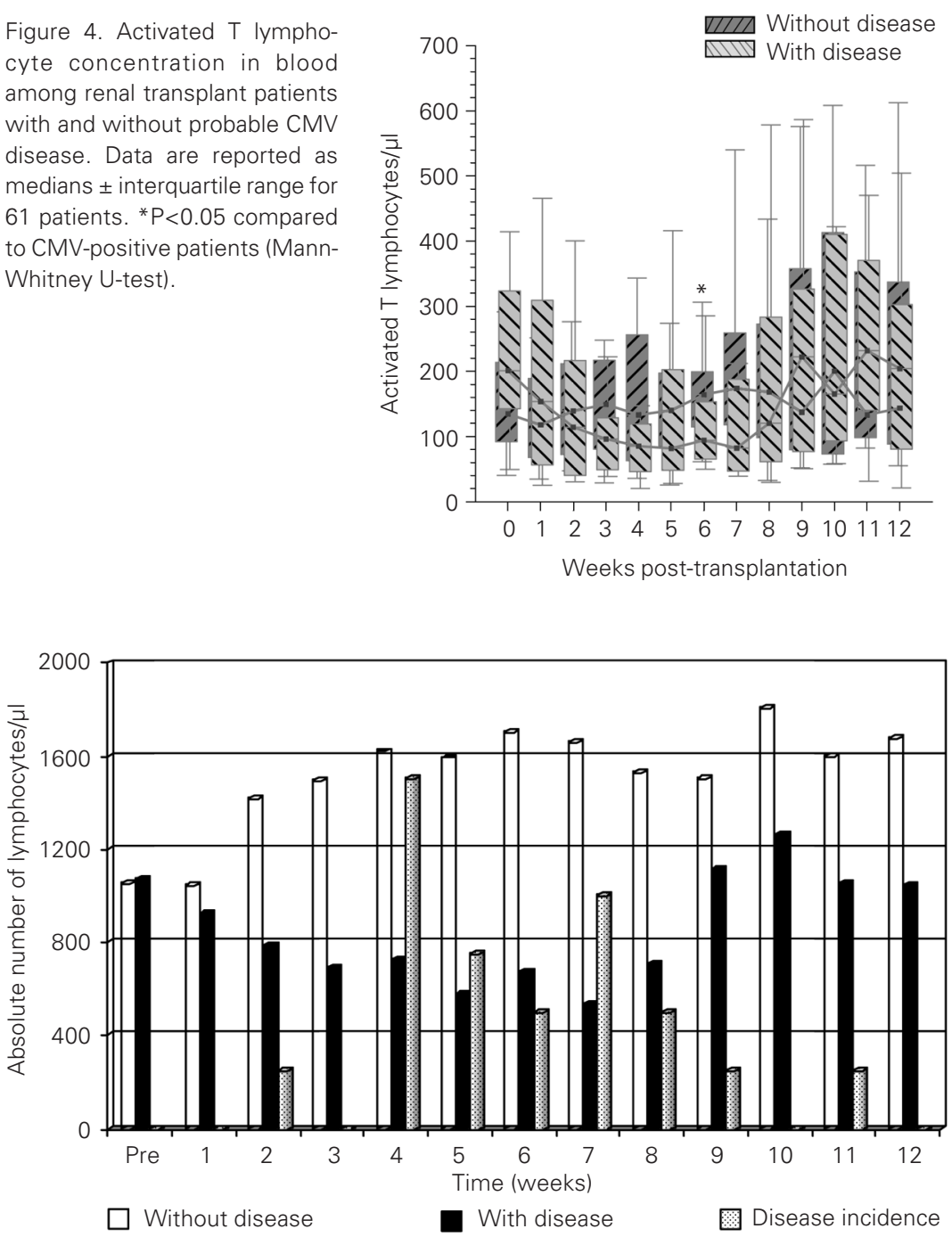

Figure 5. Total lymphocytes (CD3+) and the prevalence of CMV disease. The white columns indicate the absolute number of lymphocytes/ $\mu$ l blood in the group of patients without CMV disease $(N=40)$. The black columns indicate this same number in the group with CMV disease $(N=21)$ and the gray columns indicate the incidence of CMV disease among our patients $(N=61)$. The decrease in lymphocyte numbers precedes CMV disease. Data are reported as medians \pm interquartile range. leukocytes even before the disease is clinically apparent (12), seems to be more appropriate to guide the beginning of early treatment than viral culture, and can also permit the monitoring of these cells during infection $(2,9)$. Our findings are consistent with previous studies showing that antigenemia is a suitable method for the diagnosis of active CMV infection and acts as an early marker for active CMV infection in most patients. No antigenemia-negative patient developed CMV disease over the 3-month study period $(18,20)$, and of the 20 patients assumed to have CMV disease, 17 presented positive antigenemia prior to the appearance of clinical symptoms.

Of the 41 patients who did not show any signs of the disease at 3 months post-transplantation, 28 were positive for antigenemia at some point in the study, a fact supporting previous studies showing that CMV vire$\mathrm{mia} /$ antigenemia may occur in asymptomatic patients $(4,21,22)$.

The mean time for the occurrence of CMV disease was 6 weeks post-transplantation, which confirms the first 3 months posttransplantation as the period of highest risk to contract CMV disease (22-24).

Several groups have demonstrated that the absence of cellular immunity in organ recipients is an important factor for the development of CMV disease $(5,24-26)$. The hypothesis that the immune cell response can be monitored in vivo through immunophenotyping by flow cytometry is of great practical interest. The reproducibility of this method permits serial sample analysis, as performed in the present study. In addition, the techniques for measuring the activity of cytotoxic T lymphocytes or NK cells are more expensive and laborious and require greater time and space to carry out.

The absolute number of the cells studied did not differ between the groups with and without CMV disease before transplantation. Therefore, there was no difference in the numbers of any cells that would permit 
the prediction of behavior during the posttransplantation period, such as a tendency to contract or to resist CMV disease.

Between week 2 and 7 the absolute number of total T lymphocytes, TCD4 cells and TCD8 cells in the group with CMV showed a pronounced decrease, significantly differing from the group without disease. This period coincides with the mean period of CMV disease occurrence, characterized by a decrease in the cell response before the clinical event, with later onset of CMV disease. This pronounced reduction in the cell response seems to involve an association between the immune system and CMV disease (Figure 5).

After week 7, a rise in the absolute values of total T lymphocytes occurred, with TCD8 cells showing the most significant increase. This increase in TCD8 cells may represent an effector path of activation involved in the process of recovery from CMV disease or may be nonspecific reflecting the activation of the immune system.

Since all patients recovered from CMV disease, our study agrees with the literature suggesting that TCD8 cells participate in the recovery from CMV infection $(24,25,27,28)$. Since most patients presented infection through reactivation of the latent virus or through the acquisition of exogenous strains from transplanted organs, the TCD8 cell response does not seem to be correlated with suppression of the infection but it could be a protection against severe CMV disease (25). These effector cells seem to be involved in the control of the infection by limiting the systemic viral load.

While the role of TCD8 cells in the recovery from CMV has been shown to be of capital importance, the participation of TCD4 cells still seems to be controversial. Our results, as well as those of Rager-Zisman et al. (29), suggest that both T cell subpopulations participate in the protection against fatal CMV disease. In the absence of TCD8 cells, TCD4 cells achieve a compensatory protective activity which is absent in normal mice recovering from viral infection and TCD4 cells are believed to be instrumental in the initiation of TCD8 cell expansion via the stimulation of dendritic cells (30-32), but their role in maintaining adequate numbers and function of specific TCD8 cells is less well understood.

TCD8 and NK cells appear to play a complementary role in the recovery from CMV infection. The recovery from the disease coincides with the expansion and activation of TCD8 and NK cells. In a primary infection, both subpopulations act, while in secondary infections only TCD8 cells are supposed to be involved in the process. The activation of TCD8 cells was associated with the recovery from both primary and secondary infections and with the low risk of relapse following antiviral therapy. NK cells mainly respond upon primary infection and seem to be less important in the recovery from secondary infection or in CMV reinfection (33). A nonspecific cell response may limit viral replication and the spread of the disease at the early stage or upon primary infection, while a specific cell response would be necessary to control and keep the virus latent. In a secondary infection, this specific response could be more quickly activated, and NK cells would play a minor role.

We did not detect a significant quantitative alteration of NK cells in either group studied, probably due to the small number of primary infection cases, with the exception of week 7 , when there was a significant decrease in the absolute number of NK cells in the group with CMV disease, not detected in the group without disease. The recovery period was not followed by a significant increase in NK cells.

Our results showed an increase in the absolute number of $\mathrm{T}$ lymphocytes that express the activating antigen HLA-DR during CMV disease. This increase occurred despite the presence of cyclosporine, a drug known to act as an inhibitor of antigen HLA- 
DR expression in lymphocytes $(34,35)$. This suggests that the activation of $\mathrm{T}$ cells by virus induction is not inhibited by this drug.

Although changes in these cell subsets do not provide a definitive diagnosis of CMV disease, the consistency of the patterns described will provide diagnostic support for the suspicion of CMV disease, allowing the patient to be better monitored.

Our results have important clinical implications, possibly establishing a "risk group" for the development of CMV disease. Thus, the monitoring of different lymphocyte subsets along with antigenemia can be extremely useful in the detection of patients at high risk of developing CMV symptoms, allowing the early introduction of antiviral therapy or the reduction of immunosuppression therapy. Even though further studies are needed, especially to verify the involvement of other cell populations, our results are relevant and of interest for later studies on the involvement of the human immune system in CMV disease.

\section{References}

1. Costa SCB, Miranda SRP, Alves G, Rossi CL, Figueiredo LTM \& Costa FF (1999). Detection of cytomegalovirus infections by PCR in renal transplant patients. Brazilian Journal of Medical and Biological Research, 32: 953-959.

2. St George K \& Rinaldo Jr CR (1999). Comparison of cytomegalovirus antigenemia and culture assays in patients on and off antiviral therapy. Journal of Medical Virology, 59: 91-97.

3. Jong MD, Galasso FJ, Gazzard B, Griffiths PD, Jabs DS, Kern ER \& Spector AS (1998). Summary of the II International Symposium on Cytomegalovirus. Antiviral Research, 39: 141-162.

4. van Dam JG, Damoiseaux JG, Christiaans MH \& Bruggeman CA (2000). Acute primary infection with cytomegalovirus (CMV) in kidney transplant recipients results in the appearance of a phenotypically aberrant CD8+ T cell population. Microbiology and Immunology, 44: 1011-1017.

5. Aguado S, Tejada F, Gómez E, Gago E, Tricas L, de Oña M \& AlvarezGrande J (1995). Cytomegaloviraemia and T cell subpopulations in renal transplant patients. Nephrology, Dialysis, Transplantation, 10 (Suppl 6): 120-121.

6. Larsson S, Söderberg-Nauclér C \& Möller E (1998). Productive cytomegalovirus (CMV) infection exclusively in CD13-positive peripheral blood mononuclear cells from CMV-infected individuals. Transplantation, 65: 411-415.

7. Drago F, Aragone MG, Lugani C \& Rebora A (2000). Cytomegalovirus infection in normal and immunocompromised humans. A review. Dermatology, 200: 189-195.

8. Tegmeier GE (1986). Transfusion transmitted cytomegalovirus infections: significance and control. Vox Sanguinis, 51 (Suppl 1): 2230

9. Van den Berg AP, Van Son WJ, Janssen RAJ et al. (1992). Recovery from cytomegalovirus infection is associated with activation of peripheral blood lymphocytes. Journal of Infectious Diseases, 166: 1228-1235.

10. Beik Al, Morris AG, Higgins RM \& Lam FT (1998). Serial flow cytometric analysis of T-cell surface markers can be useful in differential diagnosis of renal allograft dysfunction. Clinical Transplantation, 12: 24-29.

11. van der Bij W, Torensma R, Van Son WJ, Anema J, Schirm J, Tegzess AM \& The TH (1988). Rapid immunodiagnosis of active cytomegalovirus infection by monoclonal antibody staining of blood leukocytes. Journal of Medical Virology, 25: 179-188.

12. Grefte JMM, van der Gun BTF, Schmolke S, van der Giessen M \& van Son SJ (1992). Cytomegalovirus antigenemia assay - identification of the viral antigen as the lower matrix protein-pp65. Journal of Infectious Diseases, 166: 683-684

13. Van der Giessen M, van den Berg AP, van der Bij W, Postma S, van Son WJ \& The TH (1990). Quantitative measurement of cytomegalovirus-specific IgG and IgM antibodies in relation to cytomegalovirus antigenemia and disease activity in kidney recipients with active cytomegalovirus infection. Clinical and Experimental Immunology, 80: 56-61.

14. Fryd DS, Peterson PK \& Ferguson R (1980). Cytomegalovirus as a risk factor in renal transplantation. Transplantation, 30: 436-439.

15. Ljung P \& Plotkin AS (1995). Workshop on CMV disease; definitions, clinical severity scores and new syndromes. Scandinavian Journal of Infectious Diseases, 99 (Suppl): 87-89.

16. Rubin $\mathrm{RH}$ (1993). Infectious disease complications of renal transplantation. Kidney International, 44: 221-236.

17. Bitsch A, Kirchner H, Dennin R, Hoyer J, Fricke L, Steinhoff J, Sack K \& Bein G (1993). The long persistence of CMV DNA in the blood of renal transplant patients after recovery from CMV infection. Transplantation, 56: 108-113.

18. Schröeder R, Mesko J, Santos A, Keitel E, Bittar A, Garcia V \& Neumann J (1999). Cytomegalovirus antigenemia and renal function post-kidney-transplantation. Transplantation Proceedings, 31: $3027-$ 3028.

19. Gotti E, Suter F, Baruzzo S, Perani V, Moioli F \& Remuzzi G (1996). Early ganciclovir therapy effectively controls viremia and avoids the need for cytomegalovirus (CMV) prophylaxis in renal transplant patients with cytomegalovirus antigenemia. Clinical Transplantation, 10: 550-555.

20. Gómez E, de Oña M, Mélon S, Alvarez R, Laures A, Rodríguez M, Pobes A \& Alvarez-Grande J (1999). Control of cytomegalovirus disease in renal transplant patients treated with prednisone, azathioprine and cyclosporine using intensive monitoring and decreased immunosuppression. Nephron, 82: 238-245.

21. Vendrell J, Segondy M, Fournier A, Huguet M, Reynes J, Ducos J \& Serre A (1991). Spontaneous in vitro secretion of antibody to cytomegalovirus (CMV) by human peripheral blood mononuclear cells: A new approach to studying the CMV-immune system interaction. 
Journal of Infectious Diseases, 164: 1-7.

22. Sester M, Sester U, Gartner B, Heine G, Girndt M, Mueller-Lantzsch N, Meyerhans A \& Kuhler H (2001). Levels of virus-specific CD4 T cells correlate with cytomegalovirus control and predict virus-induced disease after renal transplantation. Transplantation, 71: 12871294.

23. Dafoe DC, Stoolman LM, Campbell Jr DA, Lorber MI, Waskerwitz J \& Turcotte JG (1987). T cell subset patterns in cyclosporine-treated renal transplant recipients with primary cytomegalovirus disease. Transplantation, 43: 452-454.

24. Rook AH, Qinnan Jr GV, Frederick WJR, Manischewitz JF, Dantzler T, Lee BB \& Currier Jr CB (1984). Importance of cytotoxic Iymphocytes during cytomegalovirus infection in renal transplant recipients. American Journal of Medicine, 76: 385-392.

25. Reusser P, Cathomas G, Attenhofer R, Tamm M \& Thiel G (1999). Cytomegalovirus (CMV)-specific $T$ cell immunity after renal transplantation mediates protection from CMV disease by limiting the systemic virus load. Journal of Infectious Diseases, 180: 247-253.

26. Zeevi A, Morel P, Spichty K et al. (1998). Clinical significance of CMV-specific helper responses in lung transplant recipients. Human Immunology, 59: 768-775.

27. Nordøy I, Müller F, Nordal KP, Rollag H, Lien E, Aukrust P \& Frøland SS (1999). Immunologic parameters as predictive factors of cytomegalovirus disease in renal allograft recipients. Journal of Infectious Diseases, 180: 195-198.

28. Reddehase MJ, Weiland F, Munch K, Jonjic S, Luske A \& Koszinowski UH (1985). Interstitial murine cytomegalovirus pneumonia after irradiation: characterization of cells that limit viral replica- tion during established infection of the lungs. Journal of Virology, 55: 264-273.

29. Rager-Zisman B, Segeev $Y$, Blagerman S, Palmon A, Tel-Or S, Pecht M, Trainin N \& Burstein $Y$ (1994). Thymic humoral factor, THF- $\gamma 2$, enhances immunotherapy of murine cytomegalovirus (MCMV) infection by both CD4+ and CD8+ immune T cells. Immunology Letters, 39: 23-31.

30. Ridge JP, Di Rosa F \& Matzinger P (1998). A conditioned dendritic cell can be a temporal bridge between a CD4+ T-helper and a T-killer cell. Nature, 393: 474-478.

31. Schoenberger SP, Toes RE, van der Voort E, Offringa R \& Melief CJ (1998). T-cell help for cytotoxic T Iymphocytes is mediated by CD40CD40L interactions. Nature, 393: 480-483.

32. Gamadia LE, Rentenaar RJ, Baars PA, Remmerswaal EBM, Surachno S, Weel JF, Toebes M, Schumacher TN, tem Berge IJ \& van Lier RA (2001). Differentiation of cytomegalovirus-specific CD8+T cells in healthy and immunosuppressed virus carriers. Blood, 98: 754-761.

33. Van den Berg AP, van Son WJ, Tegzess AM \& The TH (1993). Cellular immune activation reflects antiviral immunity and is a favorable prognostic marker in patients with cytomegalovirus infection. Transplantation Proceedings, 25: 1419-1420.

34. Siegel DL, Fox I, Dafoe DC, Power M, Asplund M, Zellers L, Barker CF \& Prystowsky MB (1989). Discriminating rejection from CMV infection in renal allograft recipients using flow cytometry. Clinical Immunology and Immunopathology, 51: 157-171.

35. Zaia JÁ, Sissons JG, Riddell S et al. (2000). Status of cytomegalovirus prevention and treatment in 2000. Hematology, 339-355. 